UDC 614.1: 616.9: 616-002.2: 616.1

DOI: $10.21668 /$ health.risk/2021.3.15.eng

Research article

\title{
RISK OF CIRCULATORY DISEASES ON THE EXAMPLE OF HEART RHYTHM DISORDERS IN PATIENTS WITH SEROLOGICAL MARKERS OF EPSTEIN - BARR INFECTION
}

\author{
T.V. Solomay ${ }^{1,2}$, T.A. Semenenko ${ }^{3,4}$, N.N. Filatov $^{2,4}$, R.I. Khabazov ${ }^{5}$, \\ N.V. Dupik ${ }^{5}$, D.P. Dundua ${ }^{5}$, N.A. Kolyshkina ${ }^{5}$, A.V. Konev ${ }^{5}$ \\ ${ }^{1}$ The Regional Department No. 1 the FMBA of Russia, 2 bld., 6, 1 Pekhotny lane, Moscow,123182, Russian Federation \\ ${ }^{2}$ I.I. Mechnikov research Institute of vaccines and serums, 5a Maliy Kazenniy lane, Moscow, 105064, Russian Federation \\ ${ }^{3}$ The National Research Center for Epidemiology and Microbiology named after Honorary Academician N.F. Gamaleya, \\ 18 Gamaleya Str., Moscow,123098, Russian Federation \\ ${ }^{4}$ I.M. Sechenov First Moscow State Medical University, 8/1 Trubetskaya Str., Moscow, 119991, Russian Federation \\ ${ }^{5}$ The Federal Scientific and Clinical Center for Specialized medical aid and Medical technologies, the FMBA \\ of Russia, 28 Orekhoviy blvd., Moscow, 115682, Russian Federation
}

To reduce a burden of circulatory diseases (CD) is among primary tasks the state has to solve. There are available data on a contribution made by chronic inflammation on occurrence of heart and vascular diseases. Given that, it seems especially interesting to examine impacts exerted by Epstein-Barr virus infection on CD development.

The paper focuses on analyzing morbidity with infectious mononucleosis and CD in the Russian Federation over 1995-2018. 103 patients with heart rhythm disorders and 92 blood donors were examined to determine whether they had immunoglobulins to EBV antigens.

The results were statistically processed involving calculation of Pearson's linear correlation coefficient, error of correlation coefficient, validity coefficient, determination coefficient, and frequencies of EBV markers detection per 100 examined people and their confidence intervals. Differences were considered to be authentic when confidence probability was equal to $95 \%$ and confidence significance was $p<0.05$. Relative risks of heart rhythm disorders in patients with active EBV-infection were calculated as per results obtained via creating a fourfold table.

EBV was established to make a significant contribution into circulatory pathology occurrence and it was confirmed by an overall ascending trend in morbidity with infectious mononucleosis and CD in the Russian Federation in 1995-2018 and an authentic strong direct correlation between these two processes $(r=0.94 ; m=0.02 ; t=47 ; p<0.01)$ with determination being equal to 0.88. Risk of developing heart rhythm disorders was determined by active EBV-infection in case history combined with detected M-immunoglobulins to capsid EBV antigen and G-immunoglobulins to early EBV antigen, as well as an increase in concentration of G-immunoglobulins to capsid antigen in blood serum ( $R R=5.8$ and 2.3 accordingly).

These detected peculiarities require further more profound study and development of activities aimed at risk minimization.

Key words: Epstein - Barr virus, circulatory diseases, infectious mononucleosis, morbidity, heart rhythm disorders, blood donors, relative risk, positivity rate.

(c) Solomay T.V., Semenenko T.A., Filatov N.N., Khabazov R.I., Dupik N.V., Dundua D.P., Kolyshkina N.A., Konev A.V., 2021

Tatyana V. Solomay - Candidate of Medical Sciences, Deputy Director; Senior researcher at the Laboratory for Epidemiologic Analysis and Monitoring over Communicable Diseases (e-mail: solomay@rambler.ru; tel.: +7 (499) 720-49-17; ORCID: https://orcid.org/0000-0002-7040-7653).

Tatyana A. Semenenko - Doctor of Medical Sciences, Professor, Head of the Epidemiology Department, Professor at the Infectiology and Virology Department (e-mail: semenenko@gamaleya.org; tel.: +7 (499) 193-43-89; ORCID: https://orcid.org/0000-0002-6686-9011).

Nikolai N. Filatov - Doctor of Medical Sciences, Professor, Corresponding member of the RAS, Deputy Director responsible for research; Head of the Department for Epidemiology and Up-to-date Vaccination Technologies.

Robert I. Khabazov - Doctor of Medical Sciences, Professor, Deputy to Managing Director, Chief Physician, Head of the Cardiovascular Surgery Department (e-mail: khabazov119@gmail.com; tel.: +7 (926) 829-50-60; ORCID: https://orcid.org/0000-0001-6801-6568).

Nikolai V. Dupik - Head of the Cardiology Department (e-mail: dnv.74@cloud.com; tel.: +7 (911) 176-46-66; ORCID: https://orcid.org/0000-0002-3597-4265).

David P. Dundua - Doctor of Medical Sciences, Professor, Head of the Cardiology Department at the Academy for Postgraduate Studies; Head of the Cardiology Center (e-mail: david.doundoua@gmail.com; tel.: +7 (985) 992-44-87; ORCID: https://orcid.org/0000-0001-7345-0385).

Nadezhda A. Kolyshkina - Head of the Clinical and Diagnostic Laboratory, clinical laboratory diagnostics physician (e-mail: baklab_83@mail.ru; tel.: +7 (916) 214-95-34; ORCID: https://orcid.org/0000-0003-4486-5412).

Alexey V. Konev - Candidate of Medical Sciences, Head of the Cardiologic Department for Heart Rhythm Disorders Treatment (e-mail: konevalex@mail.ru; tel.: +7 (916) 715-87-72; ORCID: https://orcid.org/0000-0002-1762-6822). 
High prevalence of circulatory diseases (CD) has been given a lot of attention by experts in different fields both in the Russian Federation and abroad [1-6]. In the Russian Federation $C D$ prevalence grew by $20.7 \%$ merely over 6 years, from 2011 to 2017 [7]. Researchers point out that there is a correlation between growing $\mathrm{CD}$ cases and negative effects produced by external factors including quality of food products, drinking water and ambient air contamination, and factors related to lifestyle such as smoking alcohol abuse, hypodynamia, emotional overstrain, etc. [3, 6, 8-10]. Influence exerted by aforementioned factors on the human body is accompanied with metabolic disorders and changes in key biochemical parameters, lipid profile included [11-13]. In 2017 Russian researchers analyzed contributions made by specific biochemical parameters into a risk of ischemic heart disease; the analysis revealed that in most cases clinical specialists failed to take into account results of laboratory tests indicating that oxidative processes were disrupted and inflammation occurred [14].

At present, there is scientific evidence that it is oxidative processes that lead to changes in redox balance in internal environment of the body $[15,16]$; chronic inflammation is a typical sign of cardiovascular diseases and it leads to more severe outcomes regardless of cholesterol contents in blood serum [17].

Polish scientists published a systematic review that focused on analyzing a great number of research works; they established that pro-inflammatory cytokines had direct influence on health of the cardiovascular system. Expression of such cytokines grows over the whole lifetime and correlates with prevalence of this pathology and mortality caused by it. Growing electrical instability of cardiac muscle accompanied with heart rhythm disorders occupies a special place among other effects produced by pro-inflammatory cytokines [18].

Elevated concentrations of pro-inflammatory cytokines are markers of low-grade chronic inflammation typical for reactivation of latent viral infections including one caused by Epstein - Barr virus (EBV) [19]. A study that involved examining 222 elderly people living in the USA (their average age was $64.1 \pm 14.1$ ) revealed that higher titers of antibodies to EBV among people who were seropositive simultaneously to EBV and cytomegalovirus were associated with elevated contents of C-reactive protein and interleukin- 6 and were accompanied with deteriorating health [20]. Another research work accomplished by American scientists revealed a correlation between interleukin- 6 contents in blood plasma and titers of neutralizing antibodies to EBV-coded deoxyuridine triphosphate nucleotidohydrolase. This protein is synthesized at an early stage in virus reproduction and induces human monocytes to produce interleukin-6 and tumor necrosis factor alpha which, in their turn, play a key role in chronic inflammation development and cardiovascular pathology [21].

Analysis of the epidemiological situation regarding EBV-infection indicates it is widely spread and occurs everywhere [22-26]; there has also been an ascending trend in incidence with infectious mononucleosis in the Russian Federation over the recent years [27-29].

Given that, it seems vital to examine influence exerted by EBV-infection on cardiovascular diseases in general and heart rhythm disorders in particular.

Our research goal was to assess contribution made by EBV-infection to development of circulatory diseases on the example of heart rhythm disorders.

Materials and methods. We performed retrospective epidemiologic analysis of incidence with infectious mononucleosis and cardiovascular diseases in the Russian Federation in 1995-2018. Incidence rates were calculated per 100 thousand people. Data were taken from the Statistical Report Form No. 2 "Data on infectious and parasitic diseases" and statistical data collections "Public Healthcare in Russia" (Rosstat) ${ }^{1}$.

\footnotetext{
${ }^{1}$ Zdravookhranenie v Rossii - 2019 [Public Healthcare in Russia - 2019]. Rosstat. Available at: http://gks.ru/bgd/regl/b19_34/ (September 10, 2020) (in Russian).
} 
We calculated Pearson's linear correlation coefficient $(r)$ and standards error for correlation coefficient $(m)$. Correlation authenticity was checked with authenticity test $(t)$. Differences were considered to be authentic at the significance level being $p<0.01$ and confidence probability being $99 \%$. Calculation of determination coefficient $\left(r^{2}\right)$ allowed determining a share belonging to influence of incidence with infectious mononucleosis on CD prevalence.

We conducted a randomized controlled trial of blood serum from February 10, 2020 to June 01, 2020 to determine immunoglobulins $\mathrm{M}$ (IgM) to capsid antigen (VCA) and $\mathrm{G}$ (IgG) to capsid early (EA) and nuclear antigens (EBNA) to EBV; the trial was performed on two groups of patients through enzyme immunoassay using "Vector best" reagent kit. The first or test group was made up of 103 patients with heart rhythm disorders (there were 60 men or $58.25 \%$ (95\%; CI $48.49 \div 68.01)$ and 43 women or $41.75 \%$ $(95 \%$; CI $31.99 \div 51.51)$ aged from 21 to 65, average age being 50.27 (95\%; CI $48.41 \div 52.13)$ ). The second or reference group consisted of 92 conditionally healthy people who were active blood donors, 61 men $(66.3 \%$ (95\%; CI $56.39 \div 76.21))$ and 31 women $(33.7 \%(95 \%$; CI $23.79 \div 43.61))$ aged from 19 to 60 , average age being 41.03 (95 \%; CI $33.55 \div 48.51)$. The analyzed groups were comparable in terms of sex, age, region of living, and a period when the trial took place.

Patients with heart rhythm disorders (the test group) were selected to participate according to the following criteria:

- they were being treated in hospitals due to an acute event involving heart rhythm disorders;

- they had a diagnosed heart rhythm disorder (paroxysmal tachycardia, atrial fibrillation, atrioventricular blocks, bundle branch blocks, premature ventricular contractions with extrasystole contribution exceeding $5 \%$ of all contractions a day) confirmed with ECG and 24-hour Holter monitoring;
- they had negative results of tests aimed at determining serological and molecularbiological markers of contagion with syphilis agent, human immunodeficiency virus, hepatitis $B$ and $C$;

- their age was from 18 to 65 , both men and women were included;

- they gave their informed consent to take part in the trial.

The test group didn't include patients treated in out-patient clinics; patients with heart rhythm disorders in their case history who were in remission at the moment the trial was being conducted; patients with heart rhythm disorders not being confirmed with ECG or 24-hour Holter monitoring; patients who had myocardial infarction during 30 days prior to the trial; patients younger than 18 or older than 65; patients who didn't give their consent to take part in the trial; patients with positive results of molecular-biological test aimed at determining COVID-19 genetic material or CT-signs of COVID-19.

People for the second (reference) group, or conditionally healthy people, were selected from active donors of blood and its components according to the following inclusion criteria:

- they were men and women aged from 18 to 65 ;

- they gave their informed written consent to participate;

- they had a medical examination that included body weight measuring, body temperature taking, blood pressure measuring, determining heart rate and heart rhythm (provided there were no heart rhythm disorders); they didn't have absolute contraindications to be donors and were given a therapeutic report on absence of any therapeutic pathology at the moment their blood was taken;

- they had negative results of tests aimed at determining serological and molecularbiological markers of contagion with syphilis agent, human immunodeficiency virus, viral hepatitis $B$ and $C$;

- contents of alanine amine transferase, hemoglobin, hematocrit, erythrocytes sedimentation rate, total protein and protein 
fractions, and leukocytes count in their blood were within reference ranges determined by the RF Public Healthcare Ministry Order issued on September 14, 2001 (last edited on June 06, 2008) No. 364 "On Approval of the procedure for medical examination obligatory for a donor of blood and its components";

- they had a medical reference from their polyclinic that during 6 months prior to donorship they hadn't had any diseases or contacts with contagious patients.

People were not included into the reference group if:

- they had a disease or a contact with contagious patients during 6 months prior to the trial;

- they had positive results of tests aimed at determining syphilis, HIV-infection, viral hepatitis $B$ and $C$;

- their blood parameters determined through laboratory tests were beyond the reference ranges;

- they had at least one absolute contraindication to being a donor ${ }^{2}$ including 2-3 degree hypertension, ischemic heart disease, atherosclerosis, atherosclerotic cardiosclerosis, obliterative endarteritis, non-specific aortoarteritis, recurrent trombophlebitis, endocarditis, myocarditis, or cardiac defects;

- they were younger than 18 or older than 65 ;

- they didn't give their written informed consent to take part in the trial;

- they had positive results of molecularbiological tests aimed at determining COVID-19 genetic material or CT-signs of COVID- 19 .

People were excluded from either the test or reference group in case they refused to cooperate after the trial had begun as well as in case a sample of a biological material was missing or at least one sample of a biological material taken from an examined person was not suitable for analysis.
Statistical analysis of data obtained through laboratory tests involved calculating frequency of detecting $\operatorname{IgM}$ and $\operatorname{IgG}$ to EBV antigens (\%), average signal-to-cutoff ratios of IgM VCA and IgG EBNA for each examined group. A signal-to-cutoff ratio $(\mathrm{S} / \mathrm{Co})$ was determined by dividing optical density value of the sample being tested by the optical density values of the assay cutoff calculated according to the instruction provided with a relevant reagent kit. The result was considered positive at $\mathrm{S} / \mathrm{Co}>1$. In case the test result was positive, $\mathrm{S} / \mathrm{Co}$ value was used to estimate concentrations of specific antibodies in analyzed samples.

IgM VCA and / or IgG EA detection indicated there was active EBV-infection (either acute primary or reactivated chronic one).

Validity of differences was estimated with confidence intervals (CI). Margin of error for confidence interval was calculated as per the formula:

$$
Z \cdot \frac{\delta}{\sqrt{ } n}
$$

where $Z$ is confidence coefficient equal to 1.96 at confidence probability being equal to $95 \%$ and confidence significance being $p<0.05 ; \delta$ is standard deviation; $n$ is size of a sampling.

Relative risk $(R R)$ of heart rhythm disorders in case there was active EBV-infection and high IgG VCA concentration was calculated based on results obtained through building up a fourfold table as per the formula $\mathrm{A}:(\mathrm{A}+\mathrm{B}) / \mathrm{C}:(\mathrm{C}+\mathrm{D})$. The rate was considered positive in case its value was $>1$. Differences were considered authentic if a confidence interval for this rate didn't include 1. The upper limit of a confidence interval for average $\mathrm{S} / \mathrm{Co}$ of donors' IgG VCA was taken as the upper limit of a reference interval; when this limit was exceeded, this meant IgG VCA concentration was high (high $\mathrm{S} / \mathrm{Co}$ ).

\footnotetext{
${ }^{2}$ Contraindications are stipulated by the Order of the RF Public Healthcare Ministry issued on September 14, 2001 (last edited on June 06, 2008) No. 364 "On Approval of the procedure for medical examination obligatory for a donor of blood and its components".
} 


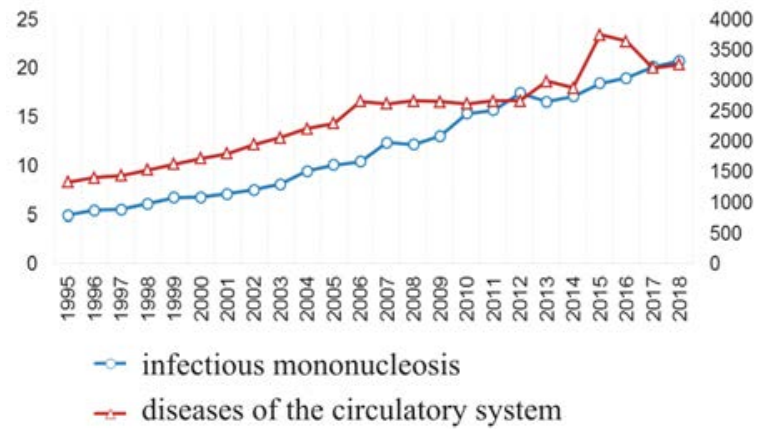

Figure. Incidence with infectious mononucleosis and prevalence of circulatory diseases in the Russian Federation in 1995-2018 (per 100 thousand people)

Results and discussion. Both incidence with infectious mononucleosis and prevalence of circulatory diseases tended to grow in the Russian Federation from 1995 to 2018 (Figure).

Correlation analysis of incidence with infectious mononucleosis in and CD prevalence in the Russian Federation in 1995-2018 revealed a strong direct correlation between them $(r=0.94$; $m=0.02)$; this correlation was authentic according to authenticity test being $t=47 ; p<0.01$.

Determination coefficient $r^{2}$ amounted to 0.88 and this indicated that contribution made by EBV into CD prevalence reached $88 \%$ and only $12 \%$ were determined by other factors.

Blood serums taken from patients with heart rhythm disorders and conditionally healthy donors were analyzed comparatively to determine immunoglobulins $\mathrm{G}$ and $\mathrm{M}$ to Epstein - Barr virus antigens in them; authentic IgM VCA prevalence was detected in the test group (Table 1). We should note that frequency of detecting IgG EA and IgG VCA was also higher in the first (test) group but those differences were not authentic.

Overall, active EBV-infection was more frequently detected by serological tests among patients with heart rhythm disorders, 12.62 (95\%; CI $6.18 \div 19.06)$ against 2.17 (95\%; CI $0 \div 5.16$ ) among donors (the reference group).

Relative risk $(R R)$ of heart rhythm disorders in case a patient had active EBV-infection amounted to $5.8(95 \%$; CI $1.3 \div 25.0)$ and difference between the groups was authentic (Table 2).
Table 1

Frequency of detecting immunoglobulins $\mathrm{M}$ and $\mathrm{G}$ to Epstein - Barr virus antigens in patients with heart rhythm disorders and donors, $\%$

\begin{tabular}{|c|c|c|c|}
\hline \multicolumn{2}{|c|}{ Ig } & $\begin{array}{c}\text { Patients with heart } \\
\text { rhythm disorders } \\
(n=103)\end{array}$ & $\begin{array}{c}\text { Donors } \\
(n=92)\end{array}$ \\
\hline \multirow{3}{*}{ IgM VCA } & abs. & 5 & 0 \\
\cline { 2 - 4 } & $\%$ & 4.85 & 0 \\
\cline { 2 - 4 } & $95 \% ;$ CI & $0.68 \div 9.02$ & $0 \div 0$ \\
\hline \multirow{3}{*}{ IgG VCA } & abs. & 103 & 90 \\
\cline { 2 - 4 } & $\%$ & 100 & 97.82 \\
\cline { 2 - 4 } IgG EA & $95 \% ;$ CI & $100 \div 100$ & $94.83 \div 100.81$ \\
\cline { 2 - 4 } & abs. & 8 & 2 \\
\cline { 2 - 4 } & $95 \% ;$ CI & $2.58 \div 12.96$ & $0 \div 5.16$ \\
\hline \multirow{2}{*}{ IgG } & abs. & 98 & 88 \\
\cline { 2 - 4 } EBNA & $\%$ & 95.15 & 95.65 \\
\cline { 2 - 4 } & $95 \% ;$ CI & $90.98 \div 99.32$ & $91.46 \div 99.84$ \\
\hline
\end{tabular}

Table 2

Distribution of examined people depending on detection of active EBV-infection markers

\begin{tabular}{|l|c|c|}
\hline \multirow{2}{*}{\multicolumn{1}{|c|}{ Examined people }} & \multicolumn{2}{c|}{$\begin{array}{c}\text { Active } \\
\text { EBV-infection markers }\end{array}$} \\
\cline { 2 - 3 } & yes & no \\
\hline $\begin{array}{l}\text { Patients with heart rhythm } \\
\text { disorders }(n=103)\end{array}$ & 13 & 90 \\
\hline Donors $(n=92)$ & 2 & 90 \\
\hline
\end{tabular}

Analysis of average signal-to-cutoff ratios in patients with heart rhythm disorders revealed authentic prevalence of $\mathrm{IgG} \mathrm{VCA}$ S/Co over IgG EBNA S/Co (Table 3). For reference, IgG VCA and IgG EBNA signalto-cutoff ratios were comparable in donors with no authentic differences between them. IgG EBNA $\mathrm{S} / \mathrm{Co}$ in patients with heart rhythm disorders didn't differ from the same ratio in donors whereas IgG VCA S/Co was authentically lower in donors than in patients with heart rhythm disorders.

Bearing in mind that donors participating in this research were considered to be conditionally healthy population and IgG VCA usually occur in blood serum during the first week since the acute primary infection started and persist there during the whole lifetime, we took a confidence interval of average IgG 
VCA S/Co for donors as a reference value in this specific research. Having compared $\operatorname{IgG}$ VCA S/Co for blood serums of patients with heart rhythm disorders and selected reference values, we detected that these values were exceeded in 57 cases (55.34\% (95\%; CI $45.69 \div 64.99)$ ) and this indicated that $\operatorname{IgG}$ VCA concentrations were high in blood serum of these patients. For reference, only 22 people among donors had elevated values of this ratio (higher than the reference level) (23.91\% $(95 \%$; CI $15.15 \div 32.67)$ ).

Table 3

Signal-to-cutoff ratios of analyzed IgG VCA and IgG EBNA samples in with heart rhythm disorders $(n=103)$ and donors $(n=92)$

\begin{tabular}{|c|c|c|c|}
\hline Ig & Group & $\begin{array}{c}\text { Average signal- } \\
\text { to-cutoff ratio }\end{array}$ & $\begin{array}{c}\text { Confidence } \\
\text { interval } \\
95 \% \text {; CI }\end{array}$ \\
\hline IgG & $\begin{array}{c}\text { Patients with } \\
\text { heart rhythm } \\
\text { disorders }\end{array}$ & 78.1 & $69.3 \div 86.9$ \\
\cline { 2 - 4 } & Donors & 40.65 & $34.6 \div 58.4$ \\
\hline \multirow{2}{*}{$\begin{array}{c}\text { IgG } \\
\text { EBNA }\end{array}$} & $\begin{array}{c}\text { Patients with } \\
\text { heart rhythm } \\
\text { disorders }\end{array}$ & 38.4 & $35.1 \div 41.7$ \\
\cline { 2 - 4 } & Donors & 35.6 & $27.4 \div 43.8$ \\
\hline
\end{tabular}

Relative risk $(R R)$ of heart rhythm disorders in case IgG VCA concentration was high amounted to $2.3(95 \%$; CI $1.5 \div 3.5)$ and the differences between the groups were authentic (Table 4).

Table 4

Distribution of examined people depending on IgG VCA concentration being higher or lower than reference values

\begin{tabular}{|l|c|c|}
\hline \multirow{2}{*}{\multicolumn{1}{|c|}{ Examined people }} & \multicolumn{2}{|c|}{$\begin{array}{c}\text { Active EBV-infection } \\
\text { markers }\end{array}$} \\
\cline { 2 - 3 } & yes & no \\
\hline $\begin{array}{l}\text { Patients with heart rhythm } \\
\text { disorders }(n=103)\end{array}$ & 57 & 46 \\
\hline Donors $(n=92)$ & 22 & 70 \\
\hline
\end{tabular}

An assumption on possible contribution made by EBV-infection into circulatory pathology in general and heart rhythm disorders in particular were based on results obtained in previous research works. Thus, myocarditis was established to be among the most widely spread clinical symptoms of infectious mononucleosis. The most typical features of myocarditis combined with EBV included damage to the heart conduction system (atrioventricular blocks, ventricular arrhythmia) and sinus tachycardia that were detected by ECG as a shift in ST segment and changes in $\mathrm{T}$ peak (flattening, twophase, or inversion) as well as atrioventricular conduction disorders (atrioventricular blocks, bundle brunch blocks) [30-34].

At the same time, the overwhelming majority of previous research works that focused on EBV contribution to arrhythmia development was clinical in their essence and dealt with heart conduction disorders in children [35-38]. This population group was most likely chosen due to high rates of incidence with infectious mononucleosis among people younger than 18 [27, 29]. It was shown that children with heart rhythm disorders in their case history also more frequently had viral infections in it (infectious mononucleosis, chicken pox, rubella, or B19 parvovirus infection) than children without this pathology [3841]. And there were cases when patients with heart rhythm disorders had genetic EBV materials detected in their serous pericardial effusion, endomyocardial tissue sampling, and venous blood [34, 36, 39, 41-43]; they also had IgM VCA in blood serum together with antibodies to antigens of working myocardium and conduction system [37, 39, 44, 45].

People older than 18 have infectious mononucleosis much less frequently than younger ones; however, they are not excluded from the epidemic process of EBV-infection which becomes a chronic latent disease with periodical reactivations in most cases after the first contact with the virus $[22,46]$. And we should also remember that circulatory diseases including those that involve heart rhythm disorders are a widely spread pathology among adult population $[7,11,13]$.

A distinctive feature of the present research is assessment of the correlation between incidence with infectious mononucleosis with EBV being its primary infectious agent and 
CD prevalence in the overall population in the Russian Federation over a long period of time (23 years) with subsequent analysis of influence exerted by frequency of detecting active EBV-infection markers and IgG VCA concentration on heart rhythm disorders by the randomized controlled trial.

The research results allow making a well-grounded conclusion that active EBVinfection makes a substantial contribution to cardiovascular system pathology in general and that involving heart rhythm disorders in particular. It gives grounds for more profound studies on the issue by experts in various spheres.

Conclusions. The accomplished research allowed making the following conclusions:

1. EBV makes a significant contribution to occurrence of circulatory pathology and this was confirmed by the common ascending trend in incidence with infectious mononucleosis and CD prevalence in the Russian Federation in 1995-2018 and the strong authentic direct correlation between these two processes $(r=0.94$; $m=0.02 ; t=47 ; p<0.01)$ with determination coefficient being equal to 0.88 .

2. Active EBV-infection in case history combined with IgM VCA and IgG EA detection and elevated IgG VCA concentration in blood serum determines a risk of heart rhythm disorders $(R R=5.8(95 \%$; CI $1.3 \div 25.0)$ and 2.3 (95\%; CI $1.5 \div 3.5)$ accordingly).

3 . The detected phenomena require further profound examination and development of activities aimed at risk minimization.

Funding. The research was not granted any sponsor support.

Conflict of interests. The authors declare there is no any conflict of interests.

\section{References}

1. de Almeida J.P.O., Ribeiro T.P., de Medeiros I.A. Aging: Molecular Pathways and Implications on the Cardiovascular System. Oxid. Med. Cell. Longev., 2017, pp. 7941563. DOI: 10.1155/2017/7941563

2. Brea A., Laclaustra M., Martorell E., Pedragosa A. Epidemiology of cerebrovascular disease in Spain. Clin. Investig. Arterioscler., 2013, vol. 25, no. 5, pp. 211-217. DOI: 10.1016/j.arteri.2013.10.006

3. Pu H., Li J., Wang P., Cui L., Wang H. The death of the circulatory system diseases in China: provincial socioeconomic and environmental perspective. Environ. Sci. Pollut. Res. Int., 2017, vol. 24, no. 11, pp. 10381-10390. DOI: 10.1007/s11356-017-8677-2

4. Gavurová B., Kubák M. Impact of Selected Socio-demographic Factors on the Development of Mortality due to Circulatory System Diseases in the Slovak Republic. Cent. Eur. J. Public. Health, 2017 , vol. 25 , no. 2 , pp. 94-103. DOI: $10.21101 /$ cejph.a5054

5. Kleeva L.P. Dynamics of natural population growth in the Russian Federation. Kompetentnost', 2020, no. 4, pp. 46-55. DOI: 10.24411/1993-8780-2020-10408 (in Russian).

6. Kontsevaya A.V., Mukaneeva D.K., Myrzamatova A.O., Balanova Yu.A., Khudyakov M.B., Drapkina O.M. Economic damage of risk factors due to their contribution to morbidity and mortality from major chronic non-communicable diseases in the Russian Federation in 2016. Kardiovaskulyarnaya terapiya i profilaktika, 2020, vol. 19, no. 1, pp. 48-55 (in Russian).

7. Hammer G.V. Mortality in Russia: status and measures to reduce it. Mezhdunarodnyi zhurnal gumanitarnyh i estestvennyh nauk, 2020, vol. 42, no. 3-2, pp. 91-99. DOI: 10.24411/2500-1000-2020-10268 (in Russian).

8. Qasim H., Karim Z.A., Rivera J.O., Khasawneh F.T., Alshbool F.Z. Impact of Electronic Cigarettes on the Cardiovascular System. J. Am. Heart Assoc., 2017, vol. 9, no. 6, pp. e006353. DOI: 10.1161/JAHA.117.006353

9. Kivimäki M., Steptoe A. Effects of stress on the development and progression of cardiovascular disease. Nat. Rev. Cardiol., 2018, vol. 15, no. 4, pp. 215-229. DOI: 10.1038/nrcardio.2017.189

10. Argacha J.F., Bourdrel T., van de Borne P. Ecology of the cardiovascular system: A focus on air-related environmental factors. Trends Cardiovasc. Med., 2018, vol. 28, no. 2, pp. 112-126. DOI: 10.1016/j.tcm.2017.07.013

11. Hamer G.V. The Retirement age is increased. Will the life of Russians be longer? Mezhdunarodnyi zhurnal gumanitarnyh i estestvennykh nauk, 2018, no. 1-12, pp. 120 (in Russian). 
12. Conroy R.M., Pyörälä K., Fitzgerald A.P., Sans S., Menotti A., De Backer G., De Bacquer D., Ducimetière P., Jousilahti P., Keil U., Njølstad I., Oganov R.G., Thomsen T., Tunstall-Pedoe H., Tverdal A., Wedel H., Whincup P., Wilhelmsen L., Graham I.M. Estimation of tem-year risk of fatal cardiovascular disease in Europe: the SCORE project. Eur. Heart J., 2003, vol. 24, no. 11, pp. 987-1003.

13. Chazova I.E., Oshchepkova E.V. Experience in fighting cardiovascular diseases in Russia. Analiticheskii vestnik, 2015, vol. 597, no. 44, pp. 4-8 (in Russian).

14. Efremova O.A., Nikitin V.M., Churnosov M.I., Kamyshnikova L.A., Lipunova E.A., Muromtsev V.V. A virtual method for assessing the risk of developing coronary heart disease in carriers of polymorphic cardiogens. Aktual'nye problemy meditsiny, 2016, vol. 247, no. 26, pp. 76-82 (in Russian).

15. Guzik T.J., Touyz R.M. Oxidative stress, inflammation, and vascular aging in hypertension. Hypertension, 2017, vol. 70, no. 4, pp. 660-667. DOI: 10.1161/HYPERTENSIONAHA.117.07802

16. García N., Zazueta C., Aguilera-Aguirre L. Oxidative Stress and Inflammation in Cardiovascular Disease. Oxid. Med. Cell. Longev., 2017, no. 2017, pp. 5853238. DOI: 10.1155/2017/5853238

17. Fioranelli M., Bottaccioli A.G., Bottaccioli F., Bianchi M., Rovesti M., Roccia M.G. Stress and Inflammation in Coronary Artery Disease: A Review Psychoneuroendocrineimmunology-Based. Front. Immunol., 2018, no. 9, pp. 2031. DOI: 10.3389/fimmu.2018.02031.

18. Smykiewicz P., Segiet A., Keag M., Żera T. Proinflammatory cytokines and ageing of the cardiovascular-renal system. Mech. Ageing Dev., 2018, no. 175, pp. 35-45. DOI: 10.1016/j. mad.2018.07.006

19. Jakovljevic A., Knezevic A., Nikolic N., Soldatovic I., Jovanovic T., Milasin J., Andric M. Herpesviruses viral loads and levels of proinflammatory cytokines in apical periodontitis. Oral Dis., 2018, vol. 24, no. 5, pp. 840-846. DOI: 10.1111/odi.12829

20. Bennett J.M., Glaser R., Malarkey W.B., Beversdorf D.Q., Peng J., Kiecolt-Glaser J.K. Inflammation and reactivation of latent herpesviruses in older adults. Brain Behav. Immun., 2012, vol. 26, no. 5, pp. 739-746. DOI: 10.1016/j.bbi.2011.11.007

21. Waldman W.J., Williams M.V. Jr., Lemeshow S., Binkley P., Guttridge D., Kiecolt-Glaser J.K., Knight D.A., Ladner K.J., Glaser R. Epstein - Barr virus-encoded dUTPase enhances proinflammatory cytokine production by macrophages in contact with endothelial cells: evidence for depressioninduced atherosclerotic risk. Brain Behav. Immun., 2008, vol. 22, no. 2, pp. 215-223. DOI: 10.1016/j.bbi.2007.07.007

22. Valeeva E.T., Akhmetshina V.T., Karamova L.M., Krasovsky V.O., Gazizova N.R. Occupational risk of health disorders of medical workers of the infectious diseases service of the Republic of Bashkortostan. Sanitarnyi vrach. 2020, no. 5, pp. 32-39. DOI: 10.33920/med-08-2005-03 (in Russian).

23. Sharifipour S., Davoodi Rad K. Seroprevalence of Epstein-Barr virus among children and adults in Tehran, Iran. New Microbes New Infect., 2020, no. 34, pp. 100641. DOI: 10.1016/j.nmni.2019.100641

24. Cui J., Yan W., Xu S., Wang Q., Zhang W., Liu W., Ni A. Anti-Epstein-Barr virus antibodies in Beijing during 2013-2017: What we have found in the different patients. PLoS One, 2018, vol. 13, no. 3, pp. e0193171. DOI: 10.1371/journal.pone.0193171

25. Beader N., Kolarić B., Slačanac D., Tabain I., Vilibić-Čavlek T. Seroepidemiological Study of Epstein-Barr Virus in Different Population Groups in Croatia. Isr. Med. Assoc. J., 2018, vol. 20, no. 2, pp. $86-90$.

26. Smatti M.K., Yassine H.M., Abu Odeh R., Al Marawani A., Taleb S.A., Althani A.A., Nasrallah G.K. Prevalence and molecular profiling of Epstein - Barr virus (EBV) among healthy blood donors from different nationalities in Qatar. PLOS One, 2017, vol. 12, no. 12, pp. e0189033. DOI: 10.1371/journal.pone.0189033

27. Burmagina I.A., Pozdeyeva M.A., Agafonov V.M. Infectious mononucleosis in the northern region. Sanitarnyi vrach, 2014, no. 11, pp. 38-41 (in Russian).

28. Solomay T.V., Semenenko T.A., Filatov N.N., Vedunova S.L., Lavrov V.F., Smirnova D.I., Gracheva A.V., Fayzuloev E.B. Reactivation of infection caused by the Epstein-Barr virus (Herpesviri- 
dae: Lymphocryptovirus, HHV-4), against the background of COVID-19: epidemiological features. Voprosy virusologii, 2021, vol. 66, no. 2, pp. 152-161. DOI: 10.36233/0507-4088-40 (in Russian).

29. Solomay T.V., Semenenko T.A. Viral hepatitis B, C and infectious mononucleosis: epidemiologic similarities and differences. Voprosy virusologii, 2020, vol. 65, no. 1, pp. 27-34. DOI: 10.36233/0507-4088-2020-65-1-27-34 (in Russian).

30. Emelyanova A.N., Kizhlo L.B., Chartorizhskaya N.N., Miromanova N.A., Vitkovsky Yu.A. Case of visceral Epstein-Barr virus Infection in a teenager. Sibirskii meditsinskii zhurnal, 2014, vol. 29, no. 1, pp. 64-68 (in Russian).

31. Levina A.S., Babachenko I.V., Chuprova S.N., Kochevaya N.V., Sharipova E.V., Ibragimova O.M. Case of heart damage in mixed streptococcal and Epstein-Barr viral infection. Pediatr, 2016, vol. 7, no. 3, pp. 147-152 (in Russian).

32. Ruzhentsova T.A., Gorelov A.V. The significance of acute respiratory viral infections in the development of chronic heart disease in children. Epidemiologiya i infektsionnye bolezni, 2012, no. 3, pp. 42-46 (in Russian)

33. Gomboeva S.B., Ryabov V.V., Shelkovnikova T.A., Usov V.Yu., Markov V.A., Karpov R.S. Case of pseudocoronary myocarditis with ST segment elevation on ECG. Rossiiskii kardiologicheskii zhurnal, 2016, vol. 139, no. 11, pp. 95-96 (in Russian).

34. Abdrakhmanova S.T., Zinkevich E.N., Rusakova N.N. Connection of viral infection with cardiovascular system damage in children. Orenburgskii meditsinskii vestnik, 2013, vol. 3, no. 1, pp. 37 (in Russian).

35. Tolstikova T.V., Bregel L.V., Kiklevich V.T., Subbotin V.M. Cardiac complications in infectious mononucleosis in children. Sibirskii meditsinskii zhurnal, 2010, no. 5, pp. 33-35 (in Russian).

36. Toubo T., Ohga S., Takada H., Suga N., Nomura A., Ohno T., Hara T. Rheumatic fevermimicking carditis as a first presentation of chronic active Epstein-Barr virus infection. Acta Paediatr., 2006, vol. 95, no. 5, pp. 614-618.

37. Balykova L.A., Ivyansky S.A., Shchekina N.V., Urzyaeva A.N., Gorbunova I.A. Differential diagnosis of inflammatory and non-inflammatory myocardial damage in a young athlete (clinical case description). Vestnik sovremennoi klinicheskoi meditsiny, 2013, vol. 6, no. 3, pp. 28-31 (in Russian).

38. Kantemirova M.G., Lutsenko Ya.V., Abrosimova A.A., Kuzmenko L.G., Poletaev A.B., Degtyareva E.A. Features of the spectrum of cardiospecific autoantibodies in children with arrhythmias. Rossiiskii vestnik perinatalogii i pediatrii, 2010, no. 1, pp. 68-72 (in Russian).

39. Blagova O.V., Popov A.V., Kogan E.A., Sulimov V.A., Osipova Yu.V., Sedov V.P., Kupriyanova A.G., Zaidenov V.A., Donnikov A.E., Kadochnikova V.V. Clinical and morphological approach to the diagnosis of "idiopathic" arrhythmias and DCMP syndrome as the basis of differential therapy. Part 2 (treatment). Ratsional'naya farmakoterapiya $v$ kardiologii, 2014, vol. 10, no. 2, pp. 195-202 (in Russian).

40. Pankuweit S., Richter A., Ruppert V., Maisch B. Familial predisposition and microbial etiology in dilated cardiomyopathy. Herz, 2009, vol. 34, no. 2, pp. 110-116. DOI: 10.1007/s00059-009-3200-2

41. Takeuchi S., Kawada J.I., Okuno Y., Horiba K., Suzuki T., Torii Y., Yasuda K., Numaguchi A., Kato T., Takahashi Y., Ito Y. Identification of potential pathogenic viruses in patients with acute myocarditis using next-generation sequencing. J. Med. Virol., 2018, vol. 90, no. 12, pp. 1814-1821. DOI: $10.1002 / j m v .25263$

42. Nikitina I.L., Vershinina T.L. Myocarditis in children: problems and solutions. Meditsinskii sovet, 2017, no. 1, pp. 238-245 (in Russian).

43. Blagova O.V., Korolyov A.V., Kogan E.A., Sulimov V.A., Osipova Yu.V., Sedov V.P., Kupriyanova A.G., Zaidenov V.A., Donnikov A.E., Kadochnikova V.V. Clinical and morphological approach to the diagnosis of "idiopathic" arrhythmias and DCMP syndrome as the basis of differential therapy. Part 1 (diagnostics). Ratsional'naya farmakoterapiya v kardiologii, 2014, vol. 10, no. 1, pp. 62-72 (in Russian).

44. Chilikina Yu.M., Sadykova D.I. Indicators of autoantibodies to myocardium in children with ventricular extrasystoles. Rossiiskii vestnik perinatologii i pediatrii, 2016, no. 4, pp. 179 (in Russian). 
45. Kantemirova M.G., Degtyareva E.A., Tsitsilashvili M.Yu., Artamonova V.A., Egorova N.Yu., Trosheva O.N. Heterophilic anticardial antibodies and cardiovascular changes in children with viral infections. Mezhdunarodnyi zhurnal interventsionnoi kardiologii, 2008, no. 16, pp. 49-54 (in Russian).

46. Yakushina S.A., Kisteneva L.B. Epstein-Barr Virus (Herpesviridae: Gammaherpesvirinae: Lymphocryptovirus: Human gammaherpesvirus 4): replication strategies. Voprosy virusologii, 2020, vol. 65, no. 4, pp. 191-202. DOI: 10.36233/0507-4088-2020-65-4-191-202 (in Russian).

Solomay T.V., Semenenko T.A., Filatov N.N., Khabazov R.I., Dupik N.V., Dundua D.P., Kolyshkina N.A., Konev A.V. Risk of circulatory diseases on the example of heart rhythm disorders in patients with serological markers of Epstein - Barr infection. Health Risk Analysis, 2021, no. 3, pp. 146-155. DOI: 10.21668/health.risk/2021.3.15.eng

Received: 31.05 .2021

Accepted: 14.09 .2021

Published: 30.09 .2021 